\title{
Allogeneic hematopoietic stem cell transplantation in chronic myeloid leukemia - Current concepts and Brazilian experience
}

\author{
Transplante de célula-tronco hematopoética na leucemia mielóide crônica - Conceitos atuais e \\ experiência brasileira
}

Cármino A. de Souza ${ }^{1}$

The approach of primary treatment for newly diagnosed CML patients has been changed due to the effectiveness and safety of imatinib mesylate (IM).$^{1-6}$ This drug has shown activity in all disease phases but the best responses are seen in the early chronic phase. ${ }^{7-11}$ However, $20 \%-30 \%$ of newly diagnosed patients using $400 \mathrm{mg}$ per day of imatinib fail to achieve a good molecular response ${ }^{11}$ and a small proportion has undetectable levels of BCR-ABL transcripts. ${ }^{12} \mathrm{BCR}-\mathrm{ABL}$ positive hematopoietic progenitors persist in the marrow of patients in CCR, indicating that the malignant progenitor may be suppressed but probably not eliminated in the course of imatinib treatment. ${ }^{13}$ Besides these considerations, concerns exist regarding the development of resistance to imatinib. ${ }^{14-18}$ Allogeneic hematopoietic stem cell transplantation (HSCT) results in long-term disease control and may cure selected patients with CML, depending on the contribution of the graft-versus-leukemia effect. ${ }^{19-21}$ Comparisons of survival rates among treatments are used to formulate general treatment policies but the decision to offer or not an allogeneic HSCT should be based on the probability of success using this procedure. Prognostic scores incorporating patient - and disease - specific variables can assist decision-making. ${ }^{22}$ The European Blood and Marrow Transplant Group (EBMT) devised a prognostic score for

${ }^{I}$ Professor Titular de Hematologia e Hemoterapia da Universidade Estadual de Campinas (Unicamp) - Campinas-SP - Brasil.

Coordenador do Hemocentro da Unicamp.

Correspondence: Cármino Antonio de Souza

Centro de Hematologia e Hemoterapia da Universidade Estadual de Campinas-Unicamp.

Cidade Universitária "Zeferino Vaz", Cx Postal 6198, Distrito de Barão Geraldo

13083-970 - Campinas- SP - Brasil

Tel.: (19) 35218740; fax: (19) 35218600

E-mail: carmino@unicamp.br. 
patients receiving allogeneic $\mathrm{HSCT}{ }^{23}$ In the IM era and in situations with limited resources we need information regarding the best chance to benefit from HSCT.

More and more data have been published in recent years regarding the use of IM as front line therapy for CML as well the newly developed TK inhibitor as Nilotinib and Dasatinib. The high level of hematological and cytogenetics responses associated to safety of the drugs created a new and important paradigm in the treatment of CML. However, the possibility of progression, are the most important concerns to be analyzed in order to choose the most effective and less toxic approach. Allogeneic HSCT has demonstrated to be able to cure CML in all clinical phases. However, the risks of high morbidity and TRM associated with acute and chronic GVHD must be considered against the benefit of HSCT. The present challenge is to identify subsets of patients to receive either TK inhibitors or HSCT. Based on our observation and in important papers published by Gratwohl ${ }^{23}$ and then by Passweg, ${ }^{22}$ patients presenting low risk scores (0 to 2) proposed by the EBMT, may be the best subgroup to be treated with HSCT. In contrast, patients treated with HSCT and presenting risk score 3 or beyond, showed low OS and DFS and high TRM and relapse rate. In addition, the status of disease had showed a high power to predict outcome. Patients in accelerated phase or in blast crisis had had a very bad prognosis. Although HSCT might be the unique treatment able to cure patients in advanced phase, only a few numbers of patients in this group may achieve a long and stable remission or definitive cure. Currently, two important points should be balance: 1 - to estimate the increase in risk if IM is given first and transplants are performed only at progression or IM failure, and $2-$ a definition of a patient cohort with such low chances of success with HSCT that it is not justifiable to use the limited resources.

The Brazilian paper report previously ${ }^{24}$ had the aim to present the results of CML patient in developing country treated with HSCT, and tried to validate the EBMT risk score. The patients in the study represent the evolution and the history of 20 years of HSCT in CML in Brazil. Our data, in an independent population, get to demonstrate that the EBMT risk score is reliable, and represents a useful guide for clinical decision making. Our data present slight differences compared with the original Gratwohl study. ${ }^{23}$ Disease status and recipient male/donor female presented the worst prognostic impact factors, whereas patients' age and time from diagnosis to transplant were not significant either in univariate or in multivariate analysis. These differences can be related to differences in patients' characteristics between the two populations: we had fewer patients in blast crisis compared to the original study ( $4 \%$ vs. $14 \%$ ), our patients were much younger, as assessed by the proportion of patients younger than 20 years ( $14 \%$ on our study vs. $8 \%$ in the original study), and the time from diagnosis to transplantation was much longer $(79 \%$ of our patients $>12$ months from diagnosis to transplantation, compared to $51 \%$ in the study by Gratwohl et al). Regarding the time from diagnosis to transplant, we speculate that in our country there is a delay in making the diagnosis and referring to a bone marrow transplant center. Concerning the results of OS and TRM according to periods of time they showed a progressive improvement which could be predictable with the improving of the support treatment, modern typing, GVHD and CMV control. EBMT activity survey published in 2004 showed the changes in disease indication over the past 15 years. ${ }^{25}$ This paper demonstrated a dramatically reduction of HSCT in the west Europe. However, in the east Europe the number of transplants increased in the same period. HSCT remains as an important alternative and countries presenting reduced resources may consider this procedure in an early phase of disease using patient' and transplant' risks. The EBMT score remains as an important instrument to decision making. Despite these slight differences, the Brazilian study validates the EBMT risk score ${ }^{23}$ and confirms its usefulness for pointdecision in a development country, especially in choosing the best treatment in the IM era.

\section{Resumo}

O transplante alogênico de célula-tronco hematopoética permanece como a única terapêutica com potencial terapêutico para a LMC in todas as fases da doença. Entretanto, os resultados com a utilização do mesilato de imatinibe são suficientemente impressionantes para deslocar a utilização do transplante para segunda ou mesmo terceira linha de tratamento dependendo da disponibilidade dos novos inibidores de tirosino quinases. A decisão para a indicação do transplante depende da fase clínica e dos achados biológicos. As recomendações da Leukemia Net e as diretrizes da NCCN nos auxiliam a escolher o melhor momento para a elaboração do transplante. Em 1998, Gratwohl e colaboradores publicaram um escore no sentido de estabelecer o risco do transplante antes de sua realização. Em 2005, um grupo brasileiro estudando mais de 1.000 pacientes em uma população independente validou o escore de risco proposto pelo grupo europeu. Neste manuscrito o autor discutirá a posição do transplante em países com limitações de recursos como o Brasil. Em 2006, a mesma escola européia publicou um estudo de monitoramento do transplante e discutiu as mudanças desta modalidade de tratamento nos últimos 15 anos e apresentou as diferenças no comportamento médico na Europa do oeste (mais rica) versus do leste (mais pobre) na indicação e utilização do transplante. A despeito dos riscos, o transplante permanece como uma terapêutica curativa válida. Atrasar a indicação ou realizar o procedimento em fases avançadas, como a fase acelerada ou blástica, aumenta o risco de mortalidade relacionada ao procedimento e reduz a probabilidade de cura. Rev. bras. hematol. hemoter. 2008; 30(Supl. 2):30-32.

Palavras-chave: Leucemia mielóide crônica (LMC); transplante alogênico de célula-tronco hematopoética (TACTH); inibidores de tirosino quinases. 


\section{References}

1. Goldman JM, Druker BJ. Chronic myeloid leukemia: current treatment options. Blood. 2001;98(7):2039-42.

2. Goldman JM. Therapeutic strategies for chronic myeloid leukemia in the chronic (stable) phase. Semin Hematol. 2003;40:10-7.

3. Goldman JM, Marin D. Management decisions in chronic myeloid leukemia. Semin Hematol. 2003;40(1 Suppl 1):10-7.

4. Goldman JM, Marin D, Olavarria E, Apperley JF. Clinical decisions for chronic myeloid leukemia in the imatinib era. Semin Hematol. 2003;40(2 Supp1 2):98-103.

5. Deininger MW, O'Brien SG, Ford JM, Druker BJ. Practical management of patients with chronic myeloid leukemia receiving imatinib. J Clin Oncol. 2003;21(8):1637-47.

6. Peggs K, Mackinnon S. Imatinib mesylate - the new gold standard for treatment of chronic myeloid leukemia. N Engl J Med. 2003; 348(11): 1048-50.

7. Druker BJ, Sawyers CL, Kantarjian H, et al. Activity of a specific inhibitor of the BCR-ABL tyrosine kinase in the blast crisis of chronic myeloid leukemia and acute lymphoblastic leukemia with the Philadelphia chromosome. N Engl J Med. 2001;344(14):1038-42.

8. Kantarjian H, Sawyers C, Hochhaus A, et al. Hematologic and cytogenetic responses to imatinib mesylate in chronic myelogenous leukemia. N Engl J Med. 2002;346(9):645-52.

9. Talpaz M, Silver RT, Druker BJ, et al. Imatinib induces durable hematologic and cytogenetic responses in patients with accelerated phase chronic myeloid leukemia: results of a phase 2 study. Blood. 2002;99(6):1928-37.

10. Sawyers CL, Hochhaus A, Feldman E, et al. Imatinib induces hematologic and cytogenetic responses in patients with chronic myelogenous leukemia in myeloid blast crisis: results of a phase II study. Blood. 2002;99(10):3530-9.

11. O'Brien SG, Guilhot F, Larson RA, et al. Imatinib compared with interferon and low-dose cytarabine for newly diagnosed chronic-phase chronic myeloid leukemia. N Engl J Med. 2003;348(11):994-1004.

12. Hughes TP, Kaeda J, Branford S, et al. Frequency of major molecular responses to imatinib or interferon alfa plus cytarabine in newly diagnosed chronic myeloid leukemia. N Engl J Med. 2003;349 (15):1423-32

13. Bhatia R, Holtz M, Niu N, et al. Persistence of malignant hematopoietic progenitors in chronic myelogenous leukemia patients in complete cytogenetic remission following imatinib mesylate treatment. Blood. 2003;101(12):4701-7.

14. Gorre ME, Mohammed M, Ellwood K, et al. Clinical resistance to STI-571 cancer therapy caused by BCR-ABL gene mutation or amplification. Science. 2001;293(5531):876-80.

15. Shah NP, Nicoll JM, Nagar B, et al. Multiple BCR-ABL kinase domain mutations confer polyclonal resistance to the tyrosine kinase inhibitor imatinib (STI571) in chronic phase and blast crisis chronic myeloid leukemia. Cancer Cell. 2002;2(2):117-25.

16. Branford S, Rudzki Z, Walsh S, et al. High frequency of point mutations clustered within the adenosine triphosphate-binding region of $\mathrm{BCR} / \mathrm{ABL}$ in patients with chronic myeloid leukemia or Ph-positive acute lymphoblastic leukemia who develop imatinib (STI571) resistance. Blood. 2002;99(9):3472-5.

17. Hochhaus A, Kreil S, Corbin AS, et al. Molecular and chromosomal mechanisms of resistance to imatinib (STI571) therapy. Leukemia. 2002;16(11):2190-6.

18. Branford S, Rudzki Z, Walsh S, et al. Detection of BCR-ABL mutations in patients with CML treated with imatinib is virtually always accompanied by clinical resistance, and mutations in the ATP phosphate-binding loop (P-loop) are associated with a poor prognosis. Blood. 2003;102(1):276-83.
19. Thomas ED, Clift RA, Fefer A, et al. Marrow transplantation for the treatment of chronic myelogenous leukemia. Ann Intern Med. 1986;104(2):155-63.

20. Goldman JM, Apperley JF, Jones L, et al. Bone marrow transplantation for patients with chronic myeloid leukemia. N Engl J Med. 1986;314(4):202-7.

21. Barrett AJ, Malkovska V. Graft-versus-leukaemia: understanding and using the alloimmune response to treat haematological malignancies. Br J Haematol. 1996;93(4):754-61.

22. Passweg JR, Walker I, Sobocinski KA, Klein JP, Horowitz MM, Giralt SA. Validation and extension of the EBMT Risk Score for patients with chronic myeloid leukaemia (CML) receiving allogeneic haematopoietic stem cell transplants. Br J Haematol. 2004;125(5):613-20.

23. Gratwohl A, Hermans J, Goldman JM, et al. Risk assessment for patients with chronic myeloid leukaemia before allogeneic blood or marrow transplantation. Chronic Leukemia Working Party of the European Group for Blood and Marrow Transplantation. Lancet. 1998;352(9134):1087-92.

24. De Souza CA, Vigorito AC, Ruiz MA, et al. Validation of the EBMT risk score in chronic myeloid leukemia in Brazil and allogeneic transplant outcome. Haematologica.2005;90(2):232-7.

25. Gratwohl A, Baldomero H, Frauendorfer K, Urbano-Ispizua A. EBMT activity survey 2004 and changes in disease indication over the past 15 years. Bone Marrow Transplant. 2006;37(12): 1069-85

O tema apresentado constou do programa do Encontro AIBE. Avaliadores: Professores Ângelo Maiolino, Cármino Antonio de Souza e Marcio Nucci.

Publicado após concordância do editor.

Conflito de interesse: não declarado.

Recebido: $24 / 04 / 2008$

Aceito: 29/04/2008 